\title{
CENTRAL-CITY/SUBURBAN INEQUALITY AND METROPOLITAN POLITICAL FRAGMENTATION
}

\author{
DAVID R. MORGAN \\ PATRICE MARESCHAL \\ University of Oklahoma
}

\begin{abstract}
To test the proposition that metropolitan governmental structure has social, economic, and racial consequences, the authors assume that the proliferation of local governments in a metropolitan area and the boundary constraints imposed on the central city have adverse effects, especially on the core city. Analyzing 97 large U.S. metropolitan statistical areas (MSAs), they found only limited support for this proposition. Of three measures of fragmentation, only two were of any consequence, one in the opposite direction predicted. The lower the central city's share of MSA population, the higher the level of fiscal health for the inner city. Also, municipal boundaries have racial consequences.
\end{abstract}

Urban America continues its sprawling ways. For more than a half century, the country has pursued one dominant vision of urban growth-unlimited low-density sprawl (Downs 1994, 3). And with considerable success. But such a model of urban development leaves a multitude of problems in its wake, especially the growing inequality between the central city and its suburbs. Some critics think this separation of resources from needs and the segregation of America's people by race and income threaten the country's longterm well-being. Other authorities, although not endorsing separation and segregation, think these disparities are largely the product of market forces. Some observers blame government, citing various ways in which public policy has contributed to central-city/suburban differences. In fact, certain scholars (Hill 1974; Rusk 1995) have blamed the politically fragmented metropolis for many of the country's urban ills. Yet the question remains

AUTHORS' NOTE: An earlier version of this article was presented at the 1996 annual meeting of the American Political Science Association.

(5) URBAn AFFAIRS REVIEW, Vol. 34, No. 4, March 1999 578-595

(C) 1999 Sage Publications, Inc. 
unsettled. To what extent does the polycentric metropolis contribute to the gap between city and suburb - the separation of resources from needs and the growing divisions by race and income?

This research will offer a test of the basic proposition that metropolitan fragmentation contributes to central-city/suburban inequality. This research will include three dependent variables - income inequality, racial segregation, and a measure of municipal fiscal health-for a large group of the nation's largest metropolitan statistical areas (MSAs). We test the effects of three measures of fragmentation: (1) the number of cities within the metropolis, (2) the percentage of MSA land area within the central city, and (3) a measure of central-city annexation.

\section{THE POLYCENTRIC METROPOLIS AND ITS CONSEQUENCES}

Three major developments characterize metropolitan America. The population continues to spread to outlying areas; indeed, most growth occurs in those suburbs most distant from the core. As urban areas deconcentrate, the proliferation of local jurisdictions increases (see Burns 1994). These separate jurisdictions perpetuate if not intensify the racial, ethnic, and class differences that have long been the bane of the large U.S. metropolis. The spreading of urban America also may increase the inequality among political entities, further widening the gap between central-city needs and suburban resources. The extent to which the existence of multiple units of government-metropolitan fragmentation-significantly contributes to the problems of the inner-city remains in dispute, however.

How important are political boundaries? Some years ago, Haar $(1972,1)$ declared that "perhaps the most intractable cause of political strife and misgovernment is the division of the earth into political jurisdictions." Eastern Europe today exemplifies the accuracy of this assertion. In the United States, critics often have lamented the lack of "fit" between the problems of large urban areas and the jurisdictional boundaries that fragment the political authority of the American metropolis. Two fundamental problems are probably the most serious - the separation of needs and resources and the perpetuation of class and racial inequality. Many observers contend that fragmentation is not random, accidental, or merely the product of neutral market forces (Danielson 1976; Logan and Schneider 1982; Newton 1975). As Downs $(1973,1)$ noted, urban development in America is not chaotic or unplanned; quite the opposite. It leads to precisely the results desired by those who dominate the process. Certain groups can segregate themselves from 
less desirable others through the creation of myriad separate localities. Much of the outward movement and the subsequent creation of separate enclaves results from class and racial antipathy and/or the desire to protect the middleclass tax base (Miller 1981).

Weiher (1991) offered an information-based theoretical model to explain the importance of political borders. The key elements are perceptions, preferences, and the jurisdictional boundaries themselves. The presence of multiple local governments within a metropolitan region provides a simple, lowcost cognitive framework to those persons engaged in a search for residential housing. Potential movers can quickly learn about community differences - the quality of schools, the affordability of housing, the presence of crime and drugs, and the racial and class composition of the various enclaves. Thus political borders represent powerful cues to persons making locational decisions. They "provide decision-makers with a frame of reference for structuring information about the characteristics of potential neighbors residing within those boundaries" (Weiher 1991, 84). In short, according to Weiher, the presence of multiple jurisdictions in itself is a causal influence on population sorting and separation by race and class.

A major assumption of this thesis is that most white urban dwellers continue to be averse to contact with blacks, especially in residential neighborhoods (Massey and Mullan 1984; Schuman and Bobo 1988). Massey and Hajnal $(1995,539)$ emphasized how the nation's segregation patterns over this century have "consistently evolved to satisfy one overriding principle - the minimization of white-black contact." They also noted a change in the level at which segregation occurs. The most recent manifestation of racial separation is at the municipal rather than the neighborhood level. Weiher's (1991, 113) research on Cook County, Illinois, and Los Angeles County confirmed that, over time, racial segregation has become organized by city rather than by neighborhood. Miller's (1981) study of Los Angeles County substantiated this pattern. Over a long period, separate incorporation became a device to segregate by race and income and to protect the tax base of middleclass communities (also see Burns 1994, 81-95).

Although the polycentric metropolis generates other allegedly adverse consequences, ${ }^{1}$ we will deal with only three: (1) the income gap between central city and suburb, (2) the fiscal burden imposed on central cities by the decentralization of jobs and people, and (3) the separation of urban dwellers by race. Over decades, abundant research documents the socioeconomic disparities between the core and its periphery (Downs 1973, 13-16; Eklund and Williams 1978; Nathan and Adams 1989; Schnore 1963). Early on, most researchers were careful to distinguish these differences by region and city size. The stereotype of the impoverished black inner city surrounded by 
affluent white suburbs applies consistently only to large MSAs and those in the Northeast (Campbell and Sacks 1967, 20-24; also see Hill and Wolman 1997). Existing disparities are growing, however. Logan and Schneider (1982) reported that income inequalities rose sharply in most metropolitan regions between 1960 and 1970. Census data for 1990 continue to reveal large income gaps between the central city and perimeter cities, especially in the Northeast and Midwest (Frey 1993, 3-36).

In addition to income and racial disparities, some studies suggested that a multinucleated structure has adverse fiscal consequences for the core city. The findings here are less conclusive. The common complaint is that the fractured metropolis creates an "institutional arrangement for promoting and protecting the unequal distribution of scarce resources" (Hill 1974, 1559). For example, Miller (1981) argued persuasively that the presence of multiple jurisdictions in the Los Angeles area is fiscally disadvantageous to poor communities. Other studies cited the continuing central-city fiscal problems resulting from the separation of needs from resources (Rusk 1995, 47). Ladd and Yinger (1989, 113-14) found that between 1972 and 1982, expenditure needs of large cities grew faster than their revenue-raising capacities. Thus the fiscal health of the average central city declined significantly during this period. $^{2}$

In sum, ample evidence over an extended period reveals that many central cities suffer significant disadvantages compared to their surrounding areas. But to what extent are these disparities the result of metropolitan governmental fragmentation? Implicitly, and at times directly, many observers saw the proliferation of local jurisdictions and the salience of political boundaries as contributing to these disparities. The results of empirical research are mixed, however.

Hill (1974) was one of the first to blame political fragmentation for creating and perpetuating inequality among MSA residents. His dependent variable was income inequality among municipalities above a population of 2,500 within a standard MSA $(N=63 ; 1960$ data). He used two measures of governmental fragmentation - total number of cities and number per capita in the MSA. Only the second indicator (per capita) was statistically significant for the inequality measure. Within a short time, two critics attacked Hill's work. The nature of his dependent variable was of particular concern. Neiman (1976) claimed that family income differences among cities is "irreparably deficient" as a way of assessing unequal municipal capacity to support public services. Ostrom (1983) also objected to Hill's methodology. She contended that the number of governments as a measure of fragmentation is flawed. Such an indicator, she wrote, is "sensitive to the size of the units for which measures of central tendency are being compared. . . 
Comparing means or medians of different-sized units can lead to false conclusions about the extent of heterogeneity in a population" (p. 98).

Two other comparative studies dealing with the effects of the fractionated metropolis on income inequality are noteworthy. Using information from 55 large MSAs, Logan and Schneider (1982) produced mixed evidence for the effects of governmental organization. They measured inequality as a ratio of median suburban household income to median family income of the central city. Their main proxy for fragmentation-number of suburbs per 1,000 residents-did not reach statistical significance. However, they found that central-city annexation was significant for 1970 but not for 1960. They also noted a strong tendency toward greater inequality in metropolitan areas where suburbs rely more heavily on the property tax. Percentage nonwhite (in the North only) also was a predictor of interjurisdictional inequality.

Using 1980 data, Bollens (1986) conducted a similar investigation. Employing a central-city/suburban income disparity dependent variable, he reported significant effects for suburban property tax reliance, annexation history, percentage black (MSA), and central-city age. Bollen's measure of fragmentation-number of noncentral cities (NCC) (more than 10,000) per 100,000 NCC residents-was not significant.

Previously, we mentioned Weiher's (1991) research showing that fragmentation increases racial disparities between the suburb and the central city. Rusk (1995, 27-30) also offered evidence that "inelastic" metropolitan areas are more racially segregated than "elastic" ones. Inelastic areas have central cities completely surrounded by suburbs; in elastic areas, the core city can expand and capture new outward growth. Although numerous studies have analyzed metropolitan racial disparities (e.g., Massey and Denton 1988; Taeuber and Taeuber 1964), few have actually included political structure as an explanatory variable.

Fiscal disparities among metropolitan communities are rampant. Still, the question of causation endures. Over the years, scholars have debated whether outlying areas exploit the center. The suburban and commuting population in particular may force the inner city to spend more for public services than it otherwise would (Davies 1965; Kasarda 1972). On the other hand, when central cities can remain economically robust, they may attract commerce from the periphery that brings them additional tax revenue. More to the point, is there evidence that greater fragmentation contributes to higher costs or greater fiscal burdens for central cities? The findings are inconclusive. Sjoquist (1982) was one of the first to discover a negative relationship between the number of municipal governments and municipal spending levels. Using a different methodology, Palumbo (1983) reached the opposite conclusion; more metropolitan governments lead to higher central-city spending. A 
similar dispute with contradictory results appeared a few years later (see Boyne 1992; Dolan 1990).

A related issue involves the broader relationship between the central city and the suburb. To what extent are they interdependent, and, in particular, is a healthy central city crucial to the overall vitality of a metropolitan area? Savitch et al. (1993) found that the core and periphery were indeed highly interdependent. In particular, flourishing central cities contributed significantly to more prosperous suburbs. Others have disagreed (for a review of this issue, see Ihlanfeldt 1995; Swanstrom 1996). In fact, Hill, Wolman, and Ford (1995) argued that the causal connection runs in the other direction. Metropolitan-wide growth should lead to narrower spatial disparities. Yet when Hill and Wolman (1997) tested that hypothesis, they came to an opposite conclusion: Robust metropolitan economies actually exacerbated the income gap between the central city and the suburb. Even in tight labor markets, they concluded that inner-city workforces do not possess enough skills to overcome the advantages suburban labor offers employers. ${ }^{3}$ These varying interpretations, although not directly attributing causality to governmental fragmentation, nonetheless highlight the continued salience of political boundaries.

In all, many disputes over the effects of metropolitan government structure remain unresolved. The research to follow sheds additional light on some of these issues. In particular, we will test three hypotheses. Greater fragmentation and lower levels of central-city annexation contribute to (1) a gap in personal income between the central city and the suburb, (2) the fiscal hardship of the core city, and (3) racial separation and isolation within the metropolitan area.

\section{RESEARCH METHODOLOGY}

This study relies primarily on an urban poverty database created under the direction of Kasarda (1993). It includes data for the 100 largest metropolitan central cities (1980 population). With exceptions noted later, the data come from standard census sources. ${ }^{4}$

The analysis includes three dependent variables. The most common measure to represent central-city/suburban disparity is the income difference between the two areas. For individual families at least, income may be an even more critical determinant of location than race. Absent the necessary financial means, a family of whatever color or race may be precluded from living in prosperous jurisdictions. Thus low-income families remain largely confined to central cities where housing is more affordable (Downs 1994, 
47). And well-off communities, through zoning restrictions and building codes, generally do not welcome residents who may be tax users rather than taxpayers. So the first dependent variable is income disparity, a simple ratio of per capita income for the area outside the central city (incorporated or not but within the MSA) to the per capita income for the central city (for 1987; $N=$ $97 ; M=1.1 ; S D=.2$ ).

The second variable is the fiscal health of the core community. Data are not readily available to compare the fiscal well-being of the central city and its surrounding area. Our argument does not depend on such a comparison in any event. The concern is directly with the fiscal fitness of the center city. Again, the basic objective is to assess whether political boundaries as manifested through metropolitan fragmentation may adversely affect central-city fiscal health. For this purpose, we rely on a standardized fiscal health measure for the central city created by Ladd and Yinger (1989, chap. 5). In general terms, it represents the relationship between a city's service needs and its revenue-raising capacity. In the authors' words, "A fiscal health index of +20 percent, for example, indicates that a city could provide public services of average quality at the selected tax burden and still have 20 percent of its capacity left over for tax cuts or high-quality services" (Ladd and Yinger $1989,8)$. The indicator is for $1986(N=56)$ and ranges from -96 (Newark, New Jersey) to +45 (Greensboro, North Carolina) with a mean of -9.7 ( $S D=$ 30.2).

The third dependent variable attempts to capture racial differences in the metropolis. As discussed in the previous section, reams have been written over the years about the "chocolate" city and the "vanilla" suburbs (see especially Massey and Denton 1993). American apartheid is Massey and Denton's phrase to describe the amazing persistence of racial segregation in and across U.S. cities. Weiher (1991) and Burns (1994) both have carefully documented the critical part that municipal boundaries play in this lamentable American dilemma.

The urban poverty data set allows us to test several measures of racial separation within the 100 metropolitan areas. Similar and good results were obtained for two of the most commonly used measures-the index of dissimilarity and an index of black isolation (see Massey and Hajnal 1995). The index of dissimilarity $(D)$ ranges from 0 to 100 and represents the proportion of the population that must move to achieve spatial integration (for a thorough discussion, see Weiher 1991, 125-30). A large value of $D$ indicates a high degree of racial separatism. The racial isolation (or exposure) indicator assesses the propensity of blacks to inhabit geographic units populated mainly by other blacks. It also varies between 0 and 100 and shows the probability of intraracial interaction within geographic units. Massey and Hajnal 
$(1995,535)$ demonstrate that when measured at the census tract level, the two indicators show very similar levels of racial segregation. We elected to use the measure of racial isolation primarily because our interest is in the effect of boundaries or geographic units rather than the more general separation of the races. For racial isolation, the range is from 9.7 to $83.7(M=56.9 ; S D=16.6$; $N=76)^{5}$

We include three measures of metropolitan political fragmentation. The first is the number of municipalities of more than 10,000 population per $1,000,000$ residents of the MSA (for 1982) — cities per MSA $(M=11.4 ; S D=$ 19.2). ${ }^{6}$ Some version of this measure is perhaps the most commonly used proxy for fragmentation. It assumes, following Weiher (1991), that more political units afford greater opportunities for separation and escape, thus contributing to central-city problems. Cities with a population of 10,000 or more should be an especially useful way of representing decentralization. Special districts even with taxing power are largely invisible (see Burns 1994, 117). School boundaries also may be indistinct to ordinary citizens. But communities of more than 10,000 residents are visible enough to prove potentially attractive to mobile urban dwellers. ${ }^{7}$

The second fragmentation measure is the population of the central city as a proportion of the MSA population. Several observers have identified such a measure as an important indicator of central-city well-being. In the words of Savitch et al. (1993), "the degree of [central-city] inclusion is a reasonably sound predictor of how well a city does relative to its suburbs." We call this variable central-city population share $(M=.39 ; S D=.20)$. A third proxy for fragmentation is a change measure designed to reflect the core city's success in expanding its borders. Rusk (1995) considers central-city elasticity, its capacity to capture new growth and development, as the key to its survival. ${ }^{8}$ The measure is created as the proportion of change in the central-city area (square miles) between 1970 and 1990 . We call it central-city area growth $(M=$ 1.43; $S D=1.23$ ) (U.S. Bureau of Census 1972, 1994).

These three fragmentation measures are the sort traditionally used in research such as this. They represent governments, population, and land area. Perhaps we should consider a functional measure of fragmentation as well. To what extent are metropolitan areas functionally integrated through cooperative arrangements and intergovernmental agreements? For years, certain scholars have argued that viewing the metropolis as a marketplace can highlight both the cooperative and competitive nature of interjurisdictional relationships (Ostrom, Tiebout, and Warren 1961; Warren 1964; for a broader view of this perspective, see Schneider 1989; Stein 1990). Yet measures of intergovernmental cooperation for a large group of cities are difficult to obtain. The Advisory Commission on Intergovernmental Relations (ACIR), 
however, did collect data on such agreements in 1988 for 667 U.S. cities. Unfortunately, the match was poor between that group and our large central cities. Using such a measure of intergovernmental relations based on the ACIR data would greatly reduce the cases for the subsequent analysis. ${ }^{9}$ Thus we reluctantly decided against its inclusion.

The remaining independent variables are basically control measures identical or similar to those used in previous research on central-city/suburban inequality. In most cases, these measures are for the central city rather than for the MSA as a whole. The assumption is that many of these variables represent forces that may "push" people and jobs outward, thus placing the central city at a disadvantage to its surrounding area.

1. Metropolitan population, 1990. We should control for population size of the MSA in the subsequent analysis. It may serve as a proxy for other unmeasured influences, although in general we would expect central cities in large MSAs to be disadvantaged compared to their suburbs.

2. Metropolitan income, 1990 (per capita). We need to be sure that any variations in income disparities and fiscal health in particular are not the result of differences in metropolitan income levels.

3. Central-city employment rate, 1990 (100 - unemployment rate). Despite the controversy over the economic interdependency of the central city and suburb, we will opt for the conventional wisdom and assume that tight labor markets in the core will reduce metropolitan spatial disparities. ${ }^{10}$

4. Percentage black, 1990 (central city). The assumption is that large proportions of the black population in the core city will be associated with differentials favoring the outlying area. It should also be especially useful in predicting MSA black isolation.

5. Age of city (the number of years since the central city reached a population of $50,000)$. Older cities are less likely to have captured areas of new growth and thus should suffer in comparison to their outlying area (source: various censuses of populations).

6. Region (North Central, South, West). We include region as a control for the tendency of southern and western MSAs to have fewer differences between the core and periphery (Northeast is the omitted category).

The interval in the years between most of the explanatory measures and the dependent variables requires comment. Most problematic is the use of a 1980 racial separation index. Our primary defense is the relatively slow rate of change for these measures over time. For example, at the county level, Massey and Hajnal $(1995,535)$ reported that indices of black-white separation varied hardly at all between 1970 and 1990 , declining from .48 to 46 . The authors did note, however, that black-white differentials at the municipal level increased somewhat, from .35 to .49 . If anything, the use of 1980 mea- 
sures may understate the actual level of racial segregation among these cities. Racial separation data for MSAs are not available for 1990.

Big-city fiscal health apparently is less stable over time than racial differences. For the late 1980s, Ladd and Yinger (1989, 316-19) found a slight improvement in the standardized fiscal health for their 56 cities. The authors commented that the economic expansion of that period, however, did nothing to reduce the enormous diversity in fiscal health across cities. Overall, their 1972 fiscal health measure correlated at .83 with the 1986 measure for the 56 central cities included in this analysis.

\section{RESULTS}

Our principal interest is in how the metropolitan fragmentation measures behave in the three regression equations. First, consider the income disparity dependent variable (column 1 in Table 1). None of the governmental organization variables reaches statistical significance. Three of the control measures do, however-metro income $(t=5.14)$, central-city employment rate $(t=-5.13)$, and age of city $(t=2.49)$. A tight central-city labor market should contribute to a narrower income gap between the center and its perimeter. We cannot infer causation here, but the results are consistent with the position of Savitch et al. (1993) rather than Hill and Wolman (1997). Specifically, a one percentage point increase in core employment leads to a decline in a suburban/central-city income disparity of .04. Income has the opposite effect. MSAs with higher per capita incomes have wider spatial income inequalities. To be sure, wealthy metro areas often coexist with poor inner cities. The evidence here, though, does not prove that as MSA income grows, its central city will become poorer. But this relationship does suggest that as incomes rise in the entire area, the central city will not necessarily benefit. Finally, as expected, older central cities have wider disparities between the core and periphery. The adjusted $R^{2}$ for this equation is $.61 .^{11}$

Next we consider the central-city fiscal health dependent variable. Here, one of the measures of fragmentation is statistically significant-central-city population share of the MSA. Surprisingly, it exhibits an unexpected sign. The larger the central city's population share of the metropolitan total, the worse its fiscal well-being $(t=-2.43) .{ }^{12}$ We had assumed that with more options for escape, the core area would lose its tax base and suffer adverse fiscal consequences. These results suggest a rethinking of this conventional wisdom. The more dominant the central city, apparently, the more fiscally at risk it becomes. ${ }^{13}$ This unexpected finding requires a bit of explanation. 
TABLE 1: Determinants of Metropolitan Income Disparity, Central-City Fiscal Health, and MSA Racial Isolation

\begin{tabular}{|c|c|c|c|}
\hline Independent Variables & $\begin{array}{c}\text { Income } \\
\text { Disparity }^{\mathrm{a}} \\
(\mathrm{N}=97)\end{array}$ & $\begin{array}{l}\text { Central-City } \\
\text { Fiscal Health } \\
\quad(\mathrm{N}=56)\end{array}$ & $\begin{array}{c}\text { MSA } \\
\text { Black Isolation } \\
(\mathrm{N}=76)\end{array}$ \\
\hline \multicolumn{4}{|l|}{ Metropolitan fragmentation } \\
\hline Cities per MSA/100,000 & $\begin{array}{c}.00 \\
(.55)\end{array}$ & $\begin{array}{c}-1.31 \\
(-1.07)\end{array}$ & $\begin{array}{l}2.01 \\
(3.82)^{* * *}\end{array}$ \\
\hline Central-city population share & $\begin{array}{l}-.02 \\
(-.25)\end{array}$ & $\begin{array}{l}-40.42 \\
(-2.43)^{*}\end{array}$ & $\begin{array}{l}3.67 \\
(.61)\end{array}$ \\
\hline Central-city area growth, 1970-1990 & $\begin{array}{l}-.00 \\
(-.16)\end{array}$ & $\begin{array}{c}.37 \\
(.04)\end{array}$ & $\begin{array}{c}-1.00 \\
(-1.32)\end{array}$ \\
\hline \multicolumn{4}{|l|}{ Control measures } \\
\hline Metro population & $\begin{array}{l}7.43 \times 10^{-10} \\
(.07)\end{array}$ & $\begin{array}{l}-3.82 \times 10^{-6} \\
(-2.17)^{*}\end{array}$ & $\begin{array}{l}2.15 \times 10^{-6} \\
(3.04)^{* *}\end{array}$ \\
\hline Metro income, per capita & $\begin{array}{l}5.54 \times 10^{-5} \\
(5.14)^{* *}\end{array}$ & $\begin{array}{c}.01 \\
(2.71)^{*}\end{array}$ & $\begin{array}{c}.00 \\
(1.47)\end{array}$ \\
\hline Central-city employment rate & $\begin{array}{c}-.04 \\
(-5.13)^{* *}\end{array}$ & $\begin{array}{l}4.77 \\
(2.99)^{* * *}\end{array}$ & $\begin{array}{c}.13 \\
(.27)\end{array}$ \\
\hline Black \% (central city) & $\begin{array}{l}-1.50 \times 10^{-4} \\
(-.12)\end{array}$ & $\begin{array}{l}-.22 \\
(-.71)\end{array}$ & $\begin{array}{c}.50 \\
(5.58)^{* * *}\end{array}$ \\
\hline Age of city & $\begin{array}{c}.01 \\
(2.49)^{*}\end{array}$ & $\begin{array}{l}-1.58 \\
(-1.35)\end{array}$ & $\begin{array}{c}.01 \\
(.02)\end{array}$ \\
\hline North Central & $\begin{array}{c}.04 \\
(.74)\end{array}$ & $\begin{array}{l}3.26 \\
(.34)\end{array}$ & $\begin{array}{c}8.78 \\
(2.60)^{*}\end{array}$ \\
\hline South & $\begin{array}{l}-.02 \\
(-.27)\end{array}$ & $\begin{array}{l}6.87 \\
(.54)\end{array}$ & $\begin{array}{l}8.29 \\
(2.08)^{*}\end{array}$ \\
\hline West & $\begin{array}{c}.01 \\
(.16)\end{array}$ & $\begin{array}{l}-5.01 \\
(-.47)\end{array}$ & $\begin{array}{l}-11.62 \\
(-2.76)^{* *}\end{array}$ \\
\hline Adjusted $R^{2}$ & .61 & .59 & .75 \\
\hline$F$ & $14.87 * *$ & $8.33 * *$ & $21.68 * *$ \\
\hline
\end{tabular}

NOTE: Coefficients are unstandardized regression slopes with $t$-values in parentheses. MSA = metropolitan statistical area.

a. Income disparity is suburban/central city (\%).

$*$ Significant at $<.05$. ** Significant at $<.01$.

Perhaps where central cities represent a substantial proportion of the area's population, the inner city encounters less pressure for fiscal restraint. This perspective comports with Zax's (1989) findings regarding metropoli$\tan$ fragmentation. Based on his research among all U.S. counties, he argued that decentralization does generate competitive forces that may promote efficient provision of public services and a smaller local public sector (also see Eberts and Gornberg 1989). It seems likely as well that a dominant central city may be a more prominent magnet for the disadvantaged of the region. 
Thus the core community becomes saddled with the extra burden of costly social services, which, of course, create intense fiscal pressures. Another related and not incompatible possibility is that a vibrant group of perimeter cities contributes to the financial well-being of the core. The central city remains a vital part of the metropolis, of course, but its fiscal fate may depend increasingly on the economic vitality of its surrounding area. Thus, consistent with the competitive theory, a larger number of sizable suburbs may be critical to a robust regional economy.

Three of the control measures for the second dependent variable (fiscal health) are statistically significant—central-city employment rate $(t=2.99)$, metro income $(t=2.71)$, and metropolitan population for $1990(t=-2.17)$. In this case, where the core jurisdiction has high employment levels and the MSA has higher per capita income, the central city should experience less financial stress. However, central cities with large populations tend to have less robust fiscal health. We might note briefly that in the bivariate case, central cities with higher proportions of African-Americans are more likely to be fiscally stressed $(r=-.39)$, but that effect disappears under controlled conditions. The adjusted level of explained variance for this equation is .59.

Finally, we come to column three in Table 1-the separation of black and white in the metropolis. Does fragmentation matter here? Indeed it does. One measure of fragmentation is a strong predictor of racial segregation in the MSA - the number of cities of 10,000 or more in the area $(t=3.82)$. A metropolis that includes a larger number of modest-sized or larger suburbs (per MSA population) should also manifest higher levels of black-white separation within the area. For every increase of one suburb (per 1,000,000 people), black racial isolation, on average, should rise by 2.01 units. Fragmentation in this form, at least, has obvious adverse consequences for whiteblack contact. Presumably, the presence of visible alternate locales encourages white flight. This effect ensues, of course, even when other metropolitan influences are taken into account. Several other control measures are statistically significant-percentage central-city population that is black, total MSA population, and all the regional variables. Highly populated metro areas tend to manifest greater racial separation than their smaller counterparts $(t=3.04)$. In addition, African-Americans are more isolated in northcentral and southern MSAs than in other regions; the western metropolis is less racially segregated. We had expected the proportion of AfricanAmericans in the core to be a powerful predictor of racial segregation. Indeed, that measure was the strongest of all independent variables for the final model $(t=5.58)$. Other things equal, the proportion of AfricanAmericans in the core city still contributes significantly to black isolation within the MSA. The adjusted $R^{2}$ here is .75 . 


\section{IS METROPOLITAN STRUCTURE BENIGN OR HARMFUL?}

For decades, reformers have lamented the adverse consequences of the multinucleated metropolis. Perhaps the most persuasive criticism has been the way suburban growth separates urban needs from resources. No doubt, the central city bears a disproportionate share of the nation's urban problems, and the suburbs generally escape responsibility for dealing with the burdens of the inner city's downtrodden and dispossessed. In Broder's (1996) words, "The racial and economic gap between cities and suburbs is probably the biggest challenge to the long-term health of this society." Even so, there is little agreement about whether the political fragmentation of the metropolis contributes independently to this unfortunate situation.

This research offers a further test of the proposition that metropolitan governmental structure has social, economic, and racial consequences. Following the reform logic, we assumed that the proliferation of local governments and the boundary constraints imposed on the central city would have at least three adverse effects. Fragmentation should contribute to greater income disparities between the central city and the suburb. It should worsen the core city's fiscal health and aggravate the racial divisions within large urban areas. These hypotheses seemed defensible even though a growing body of research has questioned the traditional reformist perspective. Public choice theory, for example, supports the position that multiple jurisdictions create a market-like environment within the metropolis. Such competition presumably compels local governments to operate more efficiently and to be more responsive to citizen-consumers.

The preceding analysis found only modest effects for metropolitan structure. We tested three measures of fragmentation, only two of which were of any consequence for separate dependent variables. Central-city population share was a useful predictor for central-city fiscal health, but the direction of that relationship was unexpected. When it comes to financial vigor, core cities apparently benefit when they are a smaller part of the metropolitan whole. One explanation relies on the effect of competition; pressures from surrounding communities keep central-city spending in check. Another interpretation emphasizes the nature of market forces operating within the metropolis. As Peterson $(1981,22)$ observes, cities seek to improve their market position-to make themselves more attractive to economic activity. And central cities? They, of course, are the "heart and node" of the MSA (Blair 1995, 17). If these core communities can remain sufficiently attractive to the hinterland, they may capture significant economic activity from affluent nonresidents and enjoy the multiplier effects of that commerce. This means more tax 
revenue and less financial strain. Perhaps core cities that are a smaller fraction of the area possess more appealing attributes and thus are especially successful in remaining vital commercial and financial centers. ${ }^{14}$ On the negative side, we discovered that MSAs with more suburbs of 10,000 and above (per $1,000,000$ residents) had higher levels of black isolation. Although our measure of segregation is areawide, it seems reasonable to assume that whites wanting to minimize interracial contact would seek non-central-city locations. Apparently, the presence of visible alternative communities makes that option easier to pursue.

So how much does metropolitan fragmentation matter? No doubt, Rusk (1995) and Broder (1996) are correct. The isolation of the inner city from the growing, white, wealthier suburbs constitutes the new shame of the cities if not the entire country. But can we blame governmental structure? Apparently not when it comes to the fiscal health of the area and even its central city. To the extent fragmentation creates a competitive environment, multiple jurisdictions do no harm at the least. Racially, the story is more complex. Fragmentation does appear to facilitate efforts by white urban dwellers to minimize contact with black residents. It would be overly simple, of course, to assume that a reduction in the proliferation of perimeter jurisdictions would substantially reduce racial segregation in U.S. metropolitan areas. That massive problem is far too intractable. The relationship between fragmentation and black isolation does remind us, though, that municipal boundaries are not inconsequential. They have abundant social meaning.

\section{NOTES}

1. The polycentric metropolis has its defenders, of course. According to public choice scholars, building on the theoretical insights of Tiebout (1956), the presence of numerous localities within the metropolitan area is beneficial. Such an arrangement gives urbanites the opportunity to select those jurisdictions that best match their tax/policy preferences (see Schneider 1985; Stein 1987; Warren 1964). Presumably, the competitive forces emanating from this quasimarket system compel local governments to become more efficient service providers and to be more responsive to citizen tax and spending preferences (Ostrom, Tiebout, and Warren 1961).

2. Bahl, Martinez-Vazquez, and Sjoquist (1992), however, identified only a slight increase in central-city/suburban fiscal inequalities between 1957 and 1987.

3. Hill and Wolman (1997) did find that if the metro labor market is very tight, then spatial disparity narrows.

4. We made several coding decisions when working from U.S. Bureau of the Census (1991) data. First, the population and income data are for the primary metropolitan statistical area (MSA), not the consolidated MSA. For example, data for San Francisco do not include Oakland; Dallas excludes Ft. Worth. However, we could not separate Long Beach from Los Angeles. Second, we made a further decision about what to include in the suburban ring. If the outlying 
area included a city of 250,000 or more, we eliminated that city on the grounds that it probably would not be considered a "suburb" in common usage. Similarly, if the outlying area contained a city that represented $50 \%$ or more of the central-city population, it was dropped. So the Kansas City, Missouri, outlying area excludes Kansas City, Kansas; Miami omits Hialeah; and Greensboro excludes Winston-Salem. For a few measures (e.g., per capita income), the data do not permit us to separate the central city from a large neighbor in the same primary MSA. For example, the outside central-city income data, used in calculating income disparity, are the same for Minneapolis and St. Paul. The same is true for Norfolk and Virginia Beach.

5. The data for MSA black isolation came originally from Wilger (1989). The formula is as follows: $b P b=\left\{\Sigma\left[B_{i}\left(b_{i} / t_{i}\right)\right]\right\} \times 100$, where $P=$ proportion of all blacks in the total MSA, $(B / T) ; B=$ black population of the metropolitan area; $B_{i}=$ proportion of all blacks in tract $i,\left(b_{i} / B\right) ; b_{i}=$ black population in tract $i$; and $t_{i}=$ total population in tract $i$. One measure of fragmentation - cities (> $10,000)$ per MSA - is statistically significant at the .01 level for equations using both $D$ and black isolation (the two measures of segregation correlate at .74). The adjusted $R^{2}$ for the racial dissimilarity equation is .64, with an $F$ of 10.66 ; explained variance for the racial isolation equation is $.75(F=21.68)$.

We also tried several measures more directly designed to compare racial separation between the central city and the suburb. The first reflects the percentage of the black MSA population living in the central city. In this case, the cities per MSA measure was not significant. However, another fragmentation measure was - the percentage of the metropolitan population residing in the central city. Where the central city is a larger part of the metropolitan population, a higher percentage of blacks are likely to inhabit the core city. This relationship between fragmentation and the racial variable may partly be artifactual, however. Where the central city contains a high proportion of the total area population, one would expect it also to contain a higher share of the African-American population. Several other core city/suburb racial variables were less useful. We tried the ratio of blacks to whites in the central city divided by a similar ratio for the suburbs. The $R^{2}$ dropped precipitously, and only one variable was statistically significant-percentage black in the core. In all, we think the results to follow indicate that the better measure of racial separation is black isolation for the metropolitan area.

6. The source for this measure is the Census of Governments (U.S. Bureau of the Census 1982, 1992). Unfortunately, more recent versions of this source no longer report the number of local governments within metropolitan areas.

7. In the equations to follow, we actually tested three related versions of urban fragmentation: (1) all local units with taxing powers, (2) cities of 10,000 or more population, and (3) cities of 10,000 and above plus all school districts. We were surprised at the continued existence of multiple school districts in many large urban areas. For example, Chicago has more than 300, and Boston has almost 150 . Perhaps the abundance of so many relatively small districts diminished the value of the combined city-school district fragmentation variable. Zax's (1989) research on counties also showed that general-purpose local governments are the key to increased metropolitan competition rather than single-purpose governments such as special districts or school districts.

8. The measure we use is similar to Rusk's (1995) elasticity index, which comprises density and the degree to which the central city expanded its limits between 1950 and 1990 .

9. Robert Stein was good enough to furnish the 1988 data for two measures-the number of intergovernmental agreements and the percentage of total agreements for each city. Including either of these two measures in the analysis reduces the $N$ to 23, 28, and 36 .

Our preliminary analysis also included a political fragmentation index (for 1980) developed by Lewis $(1996,49)$, but it also reduced our $N$ substantially and was not statistically significant in any of the three subsequent equations. 
10. We also tried a metropolitan employment measure (operationalized as $100-$ unemployment rate) in place of central-city employment. The variables are closely related $(r=.53)$, but the metro rate was not a significant predictor in any of the equations. We should note that our measure of employment differed from Hill and Wolman's (1997).

11. The equations in Table 1 manifest little multicollinearity. Only one simple relationship among independent variables is above .50; employment rate and percentage black are correlated at -.60. Also, following Studenmund $(1997,274-76)$, we checked the variance inflation factor (VIF) for each independent variable. He contends that if the VIF is above 5.0, then multicollinearity may be problematic. The VIF for one variable is above that level—southern region (VIF = 5.27). Percentage black is close to 5.0 (4.89). We ran additional equations, dropping each of these two measures sequentially. Few changes of any consequence occurred, so we believe the results overall are quite robust.

12. Here we might note that a city's fiscal well-being is related to the disparities in centralcity/suburban income. The greater the disparity, the poorer the central city's fiscal health $(r=$ -.47). Black-white racial differentiation is not prominently correlated with either of the other two dependent variables- .31 with income disparity and -.22 with fiscal health.

13. One reviewer suggested that the relationship between the central city's population share and its fiscal well-being might be curvilinear. Presumably, if the city reaches almost total dominance, it might be less fiscally at risk. The plot of the simple relationship between these two measures does not suggest any nonlinearity. Still, we added a squared term (central-city population share squared) to equation 2 in Table 1. Its presence did not increase explained variance, and neither it nor the base term was statistically significant.

14. The correlation between the central cities' percentage of the MSA and per capita income is -.41 ; where the core is smaller relative to its periphery, MSA income tends to be higher.

\section{REFERENCES}

Bahl, R., J. Martinez-Vazquez, and D. Sjoquist. 1992. Central-city suburban fiscal disparities. Public Finance Quarterly 20:420-32.

Blair, J. P. 1995. Local economic development. Thousand Oaks, CA: Sage.

Bollens, S. A. 1986. A political-ecological analysis of income inequality in the metropolitan area. Urban Affairs Quarterly 22:221-41.

Boyne, G. A. 1992. Is there a relationship between fragmentation and local government costs? A comment on Drew Dolan. Urban Affairs Quarterly 28:317-22.

Broder, D. 1996. Prosperity of suburbs, cities linked. Norman (OK) Transcript, June 26.

Burns, N. 1994. The formation of American local governments. New York: Oxford Univ. Press.

Campbell, A. K., and S. Sacks. 1967. Metropolitan America: Fiscal patterns and governmental systems. New York: Free Press.

Danielson, M. N. 1976. The politics of exclusion. New York: Columbia Univ. Press.

Davies, D. 1965. Financing urban functions and services. Law and Contemporary Problems 30:127-61.

Dolan, D. A. 1990. Local government fragmentation: Does it drive up the cost of government? Urban Affairs Quarterly 26:28-45.

Downs, A. 1973. Opening up the suburbs. New Haven, CT: Yale Univ. Press. 1994. New visions for metropolitan America. Washington, DC: Brookings Institution.

Eberts, R. W., and T. J. Gornberg. 1989. Can competition among local governments constrain government spending? Economic Review 24:2-9. 
Eklund, K. E., and O. P. Williams. 1978. The changing spatial distribution of social classes in a metropolitan area. Urban Affairs Quarterly 13:313-40.

Frey, W. H. 1993. People in places: Demographic trends in urban America. In Rediscovering urban America, edited by J. Sommer and R. Hicks. Washington, DC: U.S. Department of Housing and Urban Development.

Haar, C. M. 1972. Introduction: Metropolitanization and public services. In Metropolitanization and public services, edited by J. Wofford, D. Kirp, D. Cohen, L. Duhl, E. Haefele, and A. Kneese. Washington, DC: Resources for the Future and Johns Hopkins Univ. Press.

Hill, E. W., and H. L. Wolman. 1997. City-suburban income disparities and metropolitan area employment: Can tightening labor markets reduce the gaps. Urban Affairs Review 32:55882.

Hill, E. W., H. Wolman, and C. Ford III. 1995. Can suburbs survive without their central cities? Examining the suburban dependence hypothesis. Urban Affairs Review 32:147-74.

Hill, R. C. 1974. Separate and unequal: Governmental inequality in the metropolis. American Political Science Review 68:1557-68.

Ihlanfeldt, K. R. 1995. The importance of the central city to the regional and national economy: A review of the arguments and empirical evidence. Cityscape 1:125-50.

Kasarda, J. D. 1972. The impact of suburban population growth on central city service functions. American Journal of Sociology 77:1111-24

, ed. 1993. Urban underclass database. New York: Social Science Research Council.

Ladd, H. F., and J. Yinger. 1989. America's ailing cities. Baltimore, MD: Johns Hopkins Univ. Press.

Lewis, P. G. 1996. Shaping suburbia. Pittsburgh, PA: Univ. of Pittsburgh Press.

Logan, J. R., and M. Schneider. 1982. Governmental organizations and city/suburb income inequality, 1960-1970. Urban Affairs Quarterly 17:303-18.

Massey, D. S., and N. A. Denton. 1988. Suburbanization and segregation in U.S. metropolitan areas. American Journal of Sociology 94:592-626.

. 1993. American apartheid. Cambridge, MA: Harvard Univ. Press.

Massey, D. S., and Z. L. Hajnal. 1995. The changing geographic structure of black-white segregation in the United States. Social Science Quarterly 76:527-92.

Massey, D. S., and B. P. Mullan. 1984. Processes of Hispanic and black spatial assimilation. American Journal of Sociology 89:836-73.

Miller, G. J. 1981. Cities by contract. Cambridge: MIT Press.

Nathan, R. P., and C. F. Adams, Jr. 1989. Four perspectives on urban hardship. Political Science Quarterly 104:483-508.

Neiman, M. 1976. Communication: Social stratification and governmental inequality. American Political Science Review 70:149-54.

Newton, K. 1975. American urban politics: Social class, political structure, and public goods. Urban Affairs Quarterly 11:241-24.

Ostrom, E. 1983. The social stratification-governmental inequality thesis explored. Urban Affairs Quarterly 19:91-112.

Ostrom, V., C. M. Tiebout, and R. Warren. 1961. The organization of government in metropolitan areas: A theoretical inquiry. American Political Science Review 60:831-42.

Palumbo, G. 1983. City government expenditures and city government reality: A comment on Sjoquist. National Tax Journal 36:249-51.

Peterson, P. E. 1981. City limits. Chicago: Univ. of Chicago Press.

Rusk, D. 1995. Cities without suburbs. 2d ed. Washington, DC: Woodrow Wilson Center Press.

Savitch, H. V., D. Collins, D. Sanders, and J. Markham. 1993. Ties that bind: Central cities, suburbs, and the new metropolitan region. Economic Development Quarterly 7:341-57. 
Schneider, M. 1985. Suburban fiscal disparities and the location decisions of firms. American Journal of Political Science 29:587-605.

1989. The competitive city. Pittsburgh, PA: Univ. of Pittsburgh Press.

Schnore, L. 1963. The socio-economic status of cities and suburbs. American Sociological Review 28:76-85.

Schuman, H., and L. Bobo. 1988. Survey based experiments on white racial attitudes towards residential integration. American Journal of Sociology 94:273-99.

Sjoquist, D. L. 1982. The effect of the number of local governments on central city expense. National Tax Journal 35:79-87.

Stein, R. M. 1987. Tiebout's sorting hypothesis. Urban Affairs Quarterly 23:140-60. 1990. Urban alternatives. Pittsburgh, PA: Univ. of Pittsburgh Press.

Studenmund, A. H. 1997. Using econometrics. 3d ed. New York: Addison-Wesley.

Swanstrom, T. 1996. Ideas matter: Reflections on the new regionalism. Cityscape 2:5-21.

Taeuber, K. E., and A. F. Taeuber. 1964. White migration and socio-economic differences between cities and suburbs. American Sociological Review 29:718-29.

Tiebout, C. M. 1956. A pure theory of local expenditures. Journal of Political Economy 64:41624.

U.S. Bureau of the Census. 1972. County and city data book. Washington, DC: Government Printing Office.

- 1982. Census of governments: Local governments in metropolitan areas, vol. 5. Washington, DC: Government Printing Office.

- 1991. State and metropolitan area data book 1991. Washington, DC: Government Printing Office.

1992. Census of governments: Government organization, vol. 1. Washington, DC: Government Printing Office.

1994. County and city data book. Washington, DC: Government Printing Office.

Warren, R. O. 1964. A municipal services market model of metropolitan organization. Journal of American Institute of Planners 30:193-204.

Weiher, G. R. 1991. The fractured metropolis: Political fragmentation and metropolitan segregation. Albany: SUNY Press.

Wilger, R. 1989. Black-white residential segregation in 1980. Ph.D. diss., University of Michigan.

Zax, J. S. 1989. Is there a leviathan in your neighborhood? American Economic Review 79:56067.

David R. Morgan is a professor of political science and the Henry Bellmon Chair of Public Service at the University of Oklahoma. His work on state and urban politics and intergovernmental relations appears in various scholarly journals. The fourth edition of his book Managing Urban America, coauthored with Robert England, was published by Chatham House in 1996.

Patrice M. Mareschal is a doctoral candidate in political science at the University of Oklahoma. Her research interests include public administration, public policy, conflict resolution, and workplace issues. Her dissertation examines the mediation process in the labor relations context and identifies the determinants of successful mediation. 